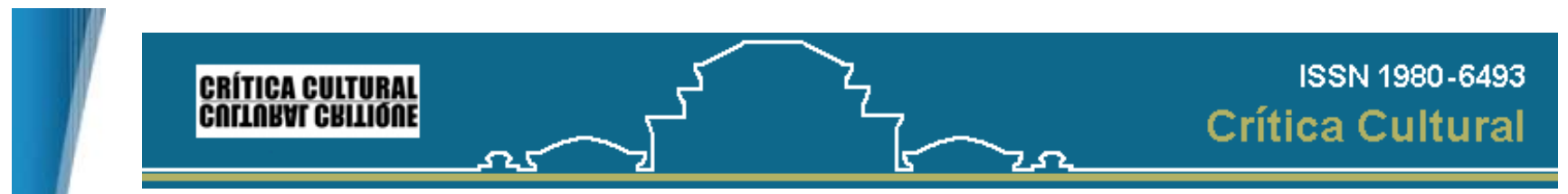

Crítica Cultural, volume 3, número 2, jul./dez. 2008

\title{
O CORTESÃO, O DÂNDI E O NÔMADE: NOTAS SOBRE PROCESSOS DE SUBJETIVAÇÃO E HISTÓRIA CULTURAL
}

Sandro Ornellas *

Resumo: Reflexão sobre diferentes processos de subjetivação que produziram três personagens conceituais ao longo da história cultural. O cortesão quinhentista, o dândi oitocentista e o nômade contemporâneo derivam de mudanças históricas nas noções de público e privado, artifício e natureza, exterioridade e interioridade, convenção e espontaneidade, aparência e essência que servem, sobretudo, para destacar as descontinuidades nos comportamentos culturais que, à primeira vista, poderiam parecer meros processos de repetição da história. Para além de figuras históricas, a aproximação dos três personagens possibilita uma reavaliação de como a cultura contemporânea se posiciona ao longo de algumas transformações históricas da subjetividade, que é, então, encarada menos como um dado psicológico e mais como um produto de processos político-histórico-culturais.

Palavras-chave: processo de subjetivação; história cultural; personagens conceituais; cortesão; dândi; nômade

1.

Quando formulou a figura do super-homem, Nietzsche provavelmente tinha guardadas em um canto da sua memória extemporânea reminiscências das aulas e idéias do seu ex-colega mais antigo da Universidade da Basiléia, com quem manteve cordial relação até o fim da sua sanidade, Jacob Burckhardt - autor do célebre $A$ cultura do Renascimento da Itália. Das idéias do sábio professor, a figura do cortesão presente nas cortes italianas parece ser invocada sub-repticiamente na doutrina nietzscheana das forças, no valor da exterioridade, na alegria trágica e na ênfase no corpo como palco privilegiado para a encenação das hierarquias político-sociais. 0 aristocratismo nietzscheano bebe bastante nas águas dessa pedagogia cortesã. Os cortesãos foram um dos elos de ligação entre os códigos de cavalaria medievais, códigos de costumes fortemente vinculados aos ideais cruzados da velha nobreza guerreira, e à civilidade que começou a emergir com o humanismo, trazendo consigo todo um novo aparato de controle e uniformização do comportamento, dos códigos e das crenças político-sociais, e que se estabelecem em definitivo no iluminismo da metade do século XVIII (cf. ELIAS, 1993). Na lógica das metamorfoses sociais, 0 cortesão encarna, então, um misto de nobreza de caráter, validada por uma espécie de fidalguia não apenas moral, mas que se pretende natural e espontânea, a fidalguia de sangue, e de educação construída através de estudo, observação e artifício. Nesse cruzamento de força naturalmente dada e vontade pedagogicamente elaborada se fazia um bom ethos cortesão.

Junto a esses conceitos e doutrinas, nasce no século XVI o livro que imprimiu alguns dos principais traços que moldaram esse personagem já perdido nas ruínas do tempo: O livro do cortesão, de Baltasar Castiglione (1478-1529), publicado em 1528. Grande sucesso, extremamente lido e influente, Castiglione, nele, ambiciona traçar o retrato do perfeito cortesão, a imagem do homem de corte que melhor traduziria alguns dos ideais da renascença italiana. 0 próprio autor era um desses personagens: lutou em batalhas quando jovem e depois foi trabalhar, convidado pelo duque Guidubaldo de Montefeltro, como secretário, diplomata e letrado na Corte de Urbino, onde apurou seus conhecimentos dos códigos cortesãos. Há, aliás, um lugar retórico, muito em voga entre séculos XV e XVIII, que pode caracterizar com bastante precisão esse personagem da corte. Refiro-me ao topos das Letras e armas. Para estudiosos desse topos, ele tem origem na religião pré-histórica do IndoEuropeu como um sistema simultaneamente cósmico, religioso e social. Nele, o Rei Soberano era ao mesmo tempo chefe político e líder espiritual, qualificando-se esse caráter duplo como ora mágico e terrificante, ora sábio e justo. Esse caráter polarizado e antinômico do governante, que também incluiria a impetuosidade da juventude e a sensatez da velhice, estará presente nos gregos no comportamento dos seus heróis épicos na Odisséia e na Ilíada (cf. REBELO, 1982, p. 195). No mundo dos poetas e retóricos latinos, esse aspecto religioso transmuta-se no topos da sapientia et fortitudo (Sabedoria e Fortaleza), que migrará diretamente para o renascimento sob o nome Armas e letras da educação cortesã.

Inúmeros e importantes personagens do período valer-se-ão dele em seus poemas. Garcilaso de la Vega, Luis de Camões e Gôngora são alguns dos nomes famosos. Comparemos seus versos, que emulam essa tradição:

Entre las armas del sangriento Marte,

Do apenas hay quien su furor contraste,

Hurté de tiempo aquesta breve suma,

Tomando, ora la espada, ora la pluma. (VEGA, 1999, p. 121)

Agora o mar, agora experimentando

Os perigos marvócios inumanos,

Qual Cânace, que à morte se condena,

Numa mão sempre a espada e noutra a pena. (CAMÕES, 1990, p. 281)

Oh fértil llano, oh sierras levantadas,

Que privilegia el cielo y dora el dia!

Oh siempre gloriosa pátria mia,

Tanto por plumas quanto por espadas! (GÔNGORA, 1988, p. 48).

É preciso dizer que todos os três conheciam o livro de Castiglione e se dedicaram com afinco ao seu ideal, que dominava as principais cortes européias. Garcilaso e Camões, por exemplo, além dos grandes poetas que foram, lutaram como soldados em batalhas, o que investe o topos da tradição e prática retórica de um poderoso elemento produtor da subjetividade característica dos humanismos dos séculos XVI e XVII. Tratar-se-ia menos de autobiografia, como muitos críticos de Camões enxergam a passagem do épico, e mais da emulação poético-retórica que ditava o que era reconhecido como valor de invenção e lugar do sujeito no período (cf. DAVOIS, 2000, p.19-20). Isso, é claro, se espraia por todos os estratos sociais, valorizando, também, as escolhas subjetivo-sociais dos que viviam nesses ambientes. Daí os famosíssimos poetas-soldados acima, que, aliás, podemos encarar como tataravôs dos escritores politicamente engajados do século XX. A retórica, mais do que aliás, podemos encarar como tataravôs dos escritores politicamente engajados do século XX. A retórica, mais do que
simplesmente um código prescritivo para o "bom uso" das letras, sempre foi, desde a Grécia, a base conceitual para as diversas codificações e práticas de representação nas sociedades, da polis helênica às cortes humanistas, passando pela Igreja medieval.

Assim, do herói antigo ao cortesão humanista, é precisamente do topos das Letras e armas que as cortes precisavam para ser administradas. Um homem que abrangesse, de um lado, valores guerreiros, públicos e políticos e, de outro lado, valores sensíveis, espirituais e intelectualizados. O soldado e o letrado. Daí que o livro de Castiglione dramatiza muitos dos processos de subjetivação que produziriam esse cortesão: os saberes administrativos, os jogos corteses de amor, as emulações para certames poéticos, a dimensão pública da vida na corte, os versos laudatórios de circunstâncias e pessoas, o manejo eficiente de armas, o chiste gracioso, os interesses corporativistas, o dito agudo e inteligente, tudo, porém, absolutamente adequado às relações e ao momento, em uma palavra, ao decoro. Em outras palavras, o bom manejo desses códigos dava ao cortesão a dignidade cívica que the cabia e o definia como merecedor de estar ali, junto aos demais membros da corte. Em suma, um aristocrata. E era como um aristocrata, como um dos melhores (aristón), que o cortesão pensava e agia. As quatro 
partes que compõem o livro de Castiglione se organizam em um todo coeso, que mescla divertimento e pedagogia de maneira exemplarmente medida. Acima de tudo um homem elegante, o cortesão de Castiglione desenvolve habilidades que se pretendem típicas da racionalidade da corte. Isto é, um misto de artificialidade calculada e essencialidade natural: a razão nominalista da retórica e da ética de Aristóteles e a dialética idealista da filosofia política de Platão se juntam nesse personagem conceitual típico das sociedades monárquicas dos Estados Absolutos.

A corporeidade para o cortesão era o meio por excelência para as práticas de representação cívicas, ou daquilo que Renato Janine Ribeiro chama de exercícios de teatralidade das cortes (1993, p. 23), pois além das armas e das guerras, era pelo corpo que o cortesão também exercia seu poder de influência política e social. São inúmeras as passagens nas quais Castiglione enfatiza a importância e a necessidade de uma educação do corpo pelo cortesão, evidenciando o traço de construção exterior, visível e pública da sua personalidade, bem de acordo com a tradição antiga e medieval, de matriz guerreira. Afirma Castiglione que:

pretendo que ele tenha uma boa compleição e membros bem formados, demonstre força, leveza e desenvoltura, e saiba todos os exercícios corporais que são exigidos de um homem de guerra. Dentre eles, penso que o primeiro deve ser manejar bem todo tipo de arma a pé e a cavalo, conhecer as posições e movimentos vantajosos destas e principalmente conhecer aquelas armas que em geral se utilizam entre fidalgos. (CASTIGLIONE, 1997, p. 36)

Pretendia-se que sua virtude refinada e sua fidalguia superior se encontravam não só na boa compleição física, mas também na elegância e destreza com que dominava os gestos, as boas maneiras e as belas letras da corte, pois eram nas festas, nos bailes, dos saraus que prestígios eram conquistados e decisões coletivas eram tomadas. Logo, a boa governança pública nas cortes tinha como fundamento o bom autogoverno privado dos seus membros. 0 saber controlar-se em meio a uma platéia de estranhos, a intimidade bem ajustada aos códigos e rituais sociais e a educação do próprio corpo pelo cortesão também implicavam na força e na eficiência para velar pelo bem-estar do corpo político da corte nas práticas públicas (cf. AUERBACH, 1983, p. 150-1), ocasiões em que o contato com demais membros da sociedade se dava de forma tão regulada e medida quanto nos jogos e ocasiões de guerra. Eis, então, uma recomendação:

Evitar ao máximo, e como um áspero e perigoso escolho, a afetação; e talvez, para dizer uma palavra nova, usar em cada coisa uma certa sprezzatura [displicência] que oculte a arte e demonstre que o que se faz e diz é feito sem esforço e quase sem pensar (CASTIGLIONE, 1997, p. 42)

Era importante, sobretudo, fazer com que todo o delineamento pelo cortesão da sua própria intimidade, fazer com que todo artifício de que lançasse mão, se apresentasse da maneira mais natural e espontânea possíveis. Com isso, ele estaria também realizando o ideal político das monarquias absolutas: encenar, pelos rituais teatralizados da corte, a "participação natural" da coletividade humana do reino no Ser Divino, que teria na figura do Rei Absoluto a cabeça do corpo coletivo da cristandade: "creio que o objetivo do cortesão (...) é ganhar a tal ponto, por meio dos atributos que lhe foram conferidos por estes senhores, a benevolência e o espírito do príncipe a quem serve" (CASTIGLIONE, 1997, p. 271). Ora, esse ideal cristão dos Estados Monárquicos aparece no livro justamente sob a forma de corpos que na sua relação teatralizada, nas suas práticas de representação, determinam os rumos políticos do poder dos Estados. 0 cortesão, assim como nenhum membro do reino, na verdade, não é dono do seu próprio corpo, que pertence diretamente ao príncipe e à coletividade pública. Sua virtude, sua autoridade moral, sua habilidade com as palavras não divergiriam muito do seu vigor, sua destreza e postura física. Ambos os lados, na verdade, convergiriam para exercícios de exterioridade e visibilidade que impunham ao cortesão cuidados intensos e permanentes no que respeita à sua posição social e responsabilidades daí advindas. Em suma, a posição e a imagem pública do membro da corte, mormente do cortesão, eram determinantes do modo como sua subjetividade se constituía. Exemplifica Renato Janine Ribeiro, a propósito do duelo, que "Não importa tanto se o ofensor teve ou não a vontade de ferir; o que se considera é se ele trouxe ou não dano à imagem pública de quem procura reparar sua honra desafiando-o às armas" (RIBEIRO, 1993, p. 23). O modelo de uma essência natural nas relações de poder na corte absoluta fazia par necessariamente com o artifício dos cálculos, dos códigos e dos protocolos que gerenciavam essas mesmas relações. Não havia nem a interioridade psicológica nem o exame de consciência para se saber da vontade do acusado. Havia, sim, o mais direto e objetivo meio de investigação possível: o plano visível da imagem pública, que fazia com que interioridade privada exterioridade pública se confundissem e não se polarizassem. Daí que justa medida é o que sempre buscava o cortesão, o que pode ser traduzido através das noções de prudência e discrição, que constituiriam o protocolo e o decoro pelo qual um bom cortesão seria reconhecido, respeitado e imitado.

A subjetividade, então, se produziria de forma ambivalente, fazendo da concepção de "pessoa" individual algo "aberto, de uma parte ao espaço social, à coletividade da corte ou à história dos homens, de outra parte, ao mais profundo de si mesmo, a Deus e a essa parcela de divindade que os habita e os anima fora de toda medida humana" (RIEU apud DAUVOIS, 2000, p. 05). A vida era encarada como sonho e o mundo como um grande teatro (theatrum mundi) - como nas pAUVOIS, 2000, p. 05). A vida era encarada como sonho e o mundo como um grande teatro (theatrum mundi) - como nas seriam alcançadas através do artifício habilmente manipulado, de modo a ocultar a sua própria manipulação, para que pudesse, com isso, chegar à essência natural. Em um típico livro de civilidade, com ensinamentos a esse homem de corte, jesuíta espanhol Baltasar Gracián, no século XVII, escreveu no seu Oraculo manual y arte de la prudencia que "As coisas não passam pelo que são, mas pelo que parecem. (...) não basta ter razão com cara de malícia" (1996, p. 74), para poucos aforismos depois, afirmar "Quanto mais qualidades, menos afetação, que costuma ser vulgar desdouro de todas elas. (...) Quanto melhor se faz uma coisa mais se há de desmentir a indústria, para que vejam que a perfeição vem do natural" (1996, p. 83-4). Todo esse teatro entre natureza e artifício na subjetivação pública do cortesão pode ser resumido no seguinte soneto de Camões, pela atração que a Dama provoca ao poeta:

Um mover de olhos, brando e piedoso,

Sem ver de quê; um riso brando e honesto,

Quase forçado; um doce e humilde gesto,

De qualquer alegria duvidoso;

Um despejo quieto e vergonhoso;

Um repouso gravíssimo e modesto;

Uma pura bondade, manifesto

Indício da alma, limpo e gracioso;

Um encolhido ousar; uma brandura;

Um medo sem ter culpa; um ar sereno;

Um longo e obediente sofrimento:

Esta foi a celeste formosura

Da minha Circe, e o mágico veneno

Que pôde transformar meu pensamento. (CAMÕES, 2003, p. 301)

A prudência do riso "quase forçado", do gesto de "alegria duvidoso", de "um medo sem ter culpa", "um longo e obediente sofrimento" e a discrição em olhos a se mover brandos, "um repouso modesto", "uma pura bondade", "um encolhido ousar", "um ar sereno" apontam para uma Dama que domina habilmente os códigos do revelar-se e ocultar-se diante do olhar dos seus pretendentes. Em ocasiões cívicas, nunca se sabia ao certo que pretendente ou interlocutor tem boas e tem más intenções. Daí a contenção dos gestos produzindo uma expressão de medida e proporção, carregada das ambivalências que os processos de subjetivação formavam durante a educação de uma dama e de um cortesão palacianos. Eles deviam reger-se, sobretudo, pela razão pública, não havendo espaço para manifestações excessivas de individualidade privada, mas, sim, de um saber governar-se, que é também um governar o "bem comum":

Quero que, se o nosso cortesão for exímio, além de nas armas, em quaisquer outras atividades, valha-se delas e faça-se por isso honrar de bom modo; e seja tão discreto e equilibrado que saiba com destreza e à propósito levar as pessoas a verem e ouvirem aquilo em que pensa ser excelente, mostrando sempre fazê-lo não por ostentação, mas por acaso antes solicitado por terceiros do que por iniciativa própria; e em tudo que tiver de fazer ou 
Richard Sennett, no seu clássico contemporâneo sobre o homem público, afirma, que "o comportamento 'público' é, antes de tudo, uma questão de agir a certa distância do eu, de sua história imediata, de suas circunstâncias e de suas necessidades" e medita que a credibilidade desse comportamento possuía dois princípios: o corpo e o discurso desse homem (1998, p 115). Mesmo que se evite corretamente confundir o homem das cortes dos séculos XVI e XVII - o cortesão - com o homem público que Sennett localiza em meados do século XVIII, este ajuda a entender um pouco daquele pelo seu sistema de crenças, que recusa a ver nos signos e códigos sociais meras capas simbólicas que encobririam as verdades do eu e do mundo. Para o cortesão, não haveria nada, nenhuma natureza, a se interpretar sob seu corpo ou seu discurso. Ao contrário, o engajamento do cortesão na execução desses códigos exteriores era função de uma crença de que esses artifícios, essas convenções de comportamento público eram convenções produtoras de realidade, de sentidos de presença, jamais falsidades, ausências ou irrealidades a ocultar as verdades invisíveis da vida.

2.

No século XIX, a sociedade de corte do Antigo Regime ficara para trás, deixando a sensação de que a vida após a Revolução furtou beleza, esperança, desejos, sonhos, magias e paraísos que poderiam dar a plenitude e a felicidade que a vida naturalmente mereceria, restando apenas viver num mundo feio, pobre, profano, reificado, demasiadamente medíocre e pequeno, no qual se exercitaria uma débil sombra da verdadeira e perdida arte de viver. De fato, as antigas sociedades de corte, com seus códigos de comportamento e de crenças, se caracterizavam, dentre outros traços, pela pequena relevância dada à intimidade e à vida privada, sendo a pessoa e seu mundo interior elementos quase invisíveis na lógica da Razão Divina que montava a organização política das monarquias absolutas. Todos os indivíduos se constituíam sujeitos aos controles dessa razão, vivida precisamente nas práticas públicas, ritualizadas e instituídas pelo poder que emanava diretamente no altíssimo topo da escala hierárquica, tal e qual se organizava a hierarquia tanto das sociedades humanas (Reis), quanto das celestes (Deus), de acordo com Pseudo-Dionísio, o Aeropagita em Hierarquia celeste: "o fim da hierarquia, é, portanto, o de conferir às criaturas, o quanto se pode, a semelhança divina e de uni-las a Deus" (2004, p. 149).

Desde a segunda metade do século XVIII, o indivíduo passa a possuir uma maior relevância e a exigir maior atenção como sujeito importante na sociedade. De um lado, é explorado até as últimas conseqüências em busca do excedente da força de trabalho de seu corpo pelos poderosos aparelhos da máquina capitalista, com Deus sendo substituído como categoria de universal pela categoria também transcendente da racionalidade ilustrada, que faz par com o capital na produtivização de absolutamente todas as instâncias da vida. De outro lado, a sua psique, sua intimidade individual, também passa a ser parâmetro para a construção de novos saberes e para o entendimento da lógica histórica e social, fazendo com que a "consciência individual" seja modelo para a definição do sujeito como elemento histórico e social em busca de "autonomia" e "felicidade" (cf. TODOROV, 2008, p. 13-29). Logo, após não necessariamente a morte de Deus, mas a sua destituição, restou ao homem construir uma idéia de "consciência histórica" a partir de uma percepção de precariedade e deficiência da realidade, tanto do ponto de vista natural, quanto social. A realidade tornara-se incompleta (ou se adquirira a "consciência" da sua incompletude) e caberia ao homem buscar completá-la, restaurá-la, melhorá-la, embelezá-la através de gestos que recuperassem aquilo que the foi furtado, fosse pelo patrão capitalista com sua mais-valia, fosse pelo Estado e seus repetidos governos, fosse pela família e pela Igreja, com suas autoritarismos e moralidades repressores. A "liberdade", então, só poderia ser viabilizada efetivamente por uma ênfase na subjetividade individual, que ao ter potencializada sua figuração assume a proeminência jurídica que se conhece tão bem no mundo moderno. Daí, então, que se pode afirmar que um dos traços característicos da modernidade é a crença em uma natureza humana a ser alcançada através do mergulho na sua própria subjetividade, na sua própria particularidade, psíquica e individual.

O homem nessa modernidade delineia então aquilo que hoje chamamos "consciência" - histórica, social e psíquica -, passando a ter o controle ou ao menos desejando assumir o controle da sua própria vida e, com isso, conquistar uma sonhada liberdade individual. Para que esse empreendimento pudesse dar resultado um dia, desenvolveram-se estratégias das mais contraditórias no âmbito dessa nova sociedade do século XIX. O nome sob o qual se encontram essas estratégias contraditórias é o de sensibilidade romântica, e algumas delas são levantadas e discutidas por Michael Löwy e Robert Sayre: revolta contra a realidade histórica e concreta do presente; crítica à reificação humana e à fragmentação social; sentimento de exílio e evasão do presente, idealização do passado e de projeções utópicas no futuro; estetização do presente; mergulho no eu, na subjetividade individual; e busca ou criação de uma unidade ou totalidade perdida (1993, p. 20-6). É como uma mescla bastante representativa de diversas dessas estratégias que emerge das práticas de representação no século XIX a figura do dândi, a "épater le bourgeois" (chocar o burguês) preocupado tão sobretudo em lucrar financeiramente e sobreviver às incertezas sociais, políticas e subjetivas, sem a beleza que a vida um dia aparentemente já possuiu.

Quando se ouve falar em dândi, é a figura de Oscar Wilde que imediatamente aparece. Nele, o dandismo assume uma faceta absolutamente provocadora quanto a sua expressividade social, pois se arma de instrumentos e gestos que, com uma clara intenção de choque, afetavam práticas sumamente aristocráticas e incompatíveis com o meio liberal-burguês da modernidade oitocentista. Com uma fusão voluntária de anacronismo classicista (e classista) e senso histórico moderno, esse homem, sem sombra de dúvida, é fruto de processos de subjetivação contraditórios como a própria modernidade, apontando, no entanto, para elementos conservadores cuja tradição é tida por contrária pelos novos tempos: uma moral superior aristocrática de recusa ao dinheiro e ao trabalho vulgar e braçal, a solidão privada como gesto de uma imaginária fidalguia, tornando-o um ser único e incomparável a qualquer outro, e o "spleen" (tédio) de um isolamento psíquico que o marca como um sinal cósmico diante dos demais homens, diante da multidão e da massa. Oscar Wilde sabia-se muito bem, nesse sentido, ao mesmo tempo, autor e personagem de si mesmo, e não apenas de si mesmo, mas do mundo que criticava em nome dos "verdadeiros ideais" de arte, beleza, amor, juventude, justiça, sociedade, etc., em tudo afastados das circunstâncias do presente. De Wilde, podemos dizer o que Baudelaire diz do seu artista no arqui-famoso ensaio de 1863, O pintor da vida moderna:

Com certeza, esse homem, tal como o descrevi, esse solitário dotado de uma imaginação ativa, sempre viajando através do grande deserto dos homens, com um objetivo sempre superior ao de um puro errante, um objetivo mais geral diferente de um prazer fugidio da circunstância. Ele busca esse algo que nos permitirá de chamar a modernidade; pois não surge melhor palavra para exprimir a idéia em questão. Trata-se, para ele, de extrair da moda o que ela pode conter de poético no histórico, de extrair o eterno do transitório (...) Numa palavra, para que toda modernidade seja digna de se tornar antiguidade, é preciso que a beleza misteriosa que a vida humana põe ali involuntariamente tenha sido extraída (BAUDELAIRE, 1993, p. 227-8)

Enquanto estilo de vida próprio a alguns processos de subjetivação da modernidade, o dândi circula em meio às massas nas ruas das cidades, mantendo-se ao mesmo tempo destacado, observando e captando filigranas de "poético", lampejos de "eterno", flashes de "antiguidade". Parece, no entanto, que esse esteta da existência não estava, então, de fato ocupado com o mundo da modernidade, isto é, não estava preocupado com o transitório, com o casual, com o diferente, com o novo que acontece diante dos seus olhos a cada instante nas vias públicas, mas com o que há de tradicional no moderno, 0 que há de repetição na diferença, de mesmo no outro, de permanência na novidade, ou seja, de "eterno do transitório". 0 gesto empreendido pelo dândi ao flertar com a modernidade é um gesto contraditório, pois que carregado de negação à própria modernidade, à própria realidade histórica, concreta e presente, em nome de um valor mais alto que busca, um "objetivo sempre superior ao puro errante". Seu gesto de recusa à realidade e ao seu tempo presente é o gesto de um pequeno-burguês, em sonhos de rebeldia, ou de um aristocrata decaído, em sonhos de ascensão. E ambos (que no fundo são - mesmo) guardam muito do conservador solipsismo entediado de uma consciência privada diante das mudanças de um mundo que não corresponde mais à "verdade natural" com a qual sonha no seu íntimo. O que corresponderia à "verdade natural" é dito por Baudelaire no seu paradigmático soneto "Correspondências":

La Nature est un temple où des vivants piliers

Laissent parfois sortir de confuses paroles;

L'homme y passe à travers des fôrêts de symboles

Qui l'observent avec des regards familiers. 
Il est de parfums frais comme des chairs d'enfants, Doux comme le hautbois, verts comme les prairies, Et d'autres, corrompus, riches et triomphants

Ayant l'expansion des choses infinies,

Comme l'ambre, le musc, le bejoin et l'encens

Qui chantent les transports des esprits et des sens. (BAUDELAIRE, 1985, p. 114) [1]

Na viagem, no oriente, no vinho, no haxixe, no sonho, na infância, na Idade Média, nos fantasmas, nos monstros, no selvagem, no amor impossível ou na morte, o dândi está, sobretudo, em busca da natureza mais natural possível, que o engenho humano não criaria (natura naturata), mas desvelaria (natura naturans). 0 que se criaria seriam os meios, os artifícios para se alcançá-la, recuperá-la, acessá-la. Toda a "ordem e beleza, / luxo, calma e volúpia" de que fala Baudelaire no seu "Convite à viagem" seriam buscados em um princípio natural, criado por Deus ou autogestado (natura naturans), que se repetiria ("ordem") e que, velado, desvelar-se-ia através do visionarismo do artista profético em meio à multidão, da sua genialidade privada, descolada de um mundo degradado. Esses paraísos são buscados pelo dândi através de artifícios humanos, demasiado humanos, mas seu estatuto de "verdade natural" não deixa dúvidas quanto a como o dândi encara a realidade em que vive. Sua concepção de artifício é naturalista, pois recusa o acaso e o jogo e aceita uma visão de mundo naturalizada, absoluta, transcendente, necessária, que preenche o pilar vazio da metafísica:

A natureza é reputada jogo de forças espontâneo e inocente, antecedente a qualquer degradação promovida pelo artifício. A duplicidade da idéia de natureza torna-se precisa e completa: a natureza é um nada (considerado "força") a partir do qual se pensa a autonomia humana, mas é também um nada (considerado "inocente") a partir do qual se pode pensar a culpabilidade dos homens. Por isso, a idéia de natureza é sempre e infalivelmente orientada para temas morais: idéias de primitividade, de autenticidade, de "puro" precedendo a poluição. A moralização do tema naturalista, muitas vezes obra de um certo século XVIII, é evidente desde a Antiguidade (ROSSET, 1989, p. 23).

Permitimo-nos, a partir daí, uma reflexão sobre as práticas de representação produzidas pelo dandismo nos seus processos de subjetivação que, entre a afetação artificiosa e a nostalgia de uma natureza perdida, tem implicações diretas para os corpos assujeitados por essa forma moral de posicionamento no mundo. Dos poemas satânicos de Baudelaire às comédias de costumes de Wilde, o dândi (i)moralista produz - através da opção pelo mal luciferino, pela ironia e pelo chiste, pela maquiagem e vestimenta excêntricas, pela postura marcial e blasé, pela pompa militar, pela indiferença de gestos teatralmente afetados - um excesso visível do que é artificial e, ao mesmo tempo, uma crítica poderosa das práticas que teatralmente afetados - um excesso visível do que é artificial e, ao mesmo tempo, uma crítica poderosa das práticas que
sustentam um mundo moderno "artificial" e "tedioso", tedioso porque artificial. Como um mistificador de si próprio e do mundo, o dândi atravessa cinicamente as paisagens mundanas, valendo-se de um desmedido "eu" romântico como um agenciador dessas representações. 0 dândi constrói uma persona pública explicitamente artificial para ocultar voluntariamente uma subjetividade "privada" e "ideal" e, com isso, também ocultar a "verdade" que só a ele permite o acesso, a visão, a miragem, a revelação para a multidão anônima: "a estética da visibilidade e o isolamento social de fundem" (SENNETT, 1998 p. 27). Dandismo e romantismo, portanto, dão as mãos e fazem um pas de deux como só a modernidade seria capaz de p. 27). Dandismo e romantismo, portanto, dão as mãos e fazem um pas de deux como só a modernidade seria capaz de
produzir, pela sua contradição definidora da moral burguesa. É aí que Baudelaire - que recusa o dandismo cínico de Wilde, quando afirma que "a palavra dândi aspira à quintessência de caráter e numa inteligência sutil de todo mecanismo moral deste mundo; mas, por outro lado, o dândi aspira à insensibilidade (...) o dândi é um eterno blasé, ou finge que é, por política e razão de casta" (1993, p. 224) - opta por um artista que se constitui como maldito, visionário, rebelde e excêntrico, em suma, o herói contraditório de uma sociedade contraditória como a moderna, pois ele próprio é filho dessa burguesia e se enreda na maré idealizadora de recusas e seduções, de naturezas e artifícios. Essas ambivalências são nítidas em um poema como "Contrariedades", de Cesário Verde, em que o olhar do sujeito para o mundo da vizinha tuberculosa entra em choque com 0 olhar para o próprio umbigo e suas veleidades.

Sentei-me à secretária. Ali defronte mora Uma infeliz, sem peito, os dois pulmões doentes: Sofre de faltas de ar, morreram-lhe os parentes E engoma para fora.

Pobre esqueleto branco entre as nevadas roupas!

Tão lívida! 0 doutor deixou-a. Mortifica.

Lidando sempre! E deve conta à botica! Mal ganha para sopas...

O obstáculo estimula, torna-nos perversos; Agora sinto-me eu cheio de raivas frias,

Por causa dum jornal me rejeitar, há dias, Um folhetim de versos.

Que mau humor! Rasguei uma epopéia morta No fundo da gaveta. 0 que produz o estudo? Mais uma redação, das que elogiam tudo, Me tem fechado a porta.

E a tísica? Fechada, e com o ferro aceso I gnora que a asfixia a combustão das brasas, Não foge do estendal que the umedece as casas, E fina-se ao desprezo!

Perfeitamente. Vou findar sem azedume. Quem sabe se depois, eu rico e noutros climas,

Conseguirei reler essas antigas rimas, Impressas em volume?

$$
(\ldots)
$$


Que mundo! Coitadinha! (VERDE, 1982, p. 51-3)

O discurso do poema de Cesário claramente contrapõe o "eu" individualista e interior do sujeito ao mundo exterior da vizinha tísica, que, diante dos caprichos do poeta, termina ridicularizada numa representação grotesca da precariedade da vida. É contra o corpo, enquanto meio de expressão pública da subjetividade, que o "eu" romântico vai se colocar, ainda como um crente na Razão Divina, em um princípio natural que sua "consciência" - histórica, social e individual - representaria: princípio regulador, ordenador, punitivo e moralizador desse mundo.

É aí que os processos de subjetivação e de sociabilidade modernos dão as mãos com a hipocrisia. A partir de, pelo menos, o século XIX, não se encara mais as práticas burguesas de representação e de teatralidade públicas, os códigos impessoais de relacionamento, como necessariamente autênticos e verdadeiros. A vida pública e social burguesa é creditada como produtora de gestos, "na melhor das hipóteses, como formais e áridos e, na pior, como falsos", dissimulados, enganadores e hipócritas (SENNETT, 1998, p. 16-9). A desconfiança diante de qualquer gesto de expressão em público é a regra e o valor ("crítico"); passa-se a desconfiar de tudo, até mesmo do sentimento, quando exposto publicamente. E o homem público sofre com isso, sofre com a perda do Paraíso, que passa a pertencer apenas ao espaço privado, tornando-se o espaço público associado quase que somente ao que há de artificial e excessivo na figura afetada do dândi. 0 mundo público da burguesia formularia e institucionalizaria o escamoteamento de qualquer gesto que se quisesse naturalmente autêntico, que passa a ser visto como hipócrita ou encarado com o cinismo característico do dândi wildeano. A vida pública, se não acompanha a lógica da "verdade natural" do indivíduo, é criticada e denunciada. Vemos isso na novela exemplar de Eça de Queiróz, Alves \& Cia, na qual se monta a denúncia de como o mundo privado se encontra subjugado pela falsa moral do mundo público. Este é descrito através de cenas cujas convenções e códigos de relacionamento são mostrados como absolutamente falsos e dissimulados, quando contrapostos à subjetividade privada, natural e espontânea do personagem Alves diante de um adultério sofrido. 0 mal privado é sofrido publicamente, exposto e submetido à moral coletiva de todos que, num primeiro momento, cobram de Alves que "limpe sua honra", mas que com a sua disposição de levar adiante o duelo, voltam atrás nas suas cobranças até o convencerem de desistir do ato a que 0 incentivaram. Na novela, vê-se toda a frágil e ridicularizada moral individual à mercê de uma bruta moral pública. A aparência das instituições "casamento" entre Alves e Ludovina, e "sociedade comercial", entre Alves (marido traído) e Machado (amante), é sustentada ao final da história apenas por caminhos modernamente adaptados ao dualismo público/privado, isto é, mantém-se através da falsa moral que não torna visível publicamente o que se sente, se pensa e se faz privadamente, ocultando, assim, a verdade. E não se fala mais nisso.

3.

Na modernidade, o espaço público será dominado por um sujeito crítico que se confunde com sua individualidade subjetiva e impõe ao outro que com ele compartilha esse espaço uma moral muitas vezes hipócrita, pois que o público é moralizado em nome de interesses particulares, apesar do discurso que preconiza o público como domínio experimentado coletiva e racionalmente. A verdade, no âmbito da modernidade, será submetida permanentemente à avaliação de um "sujeito crítico universal" que elabora seu discurso a partir de um lugar agenciado como fora do tempo e do espaço, sujeito transcendental, mesmo que sem Deus. Ao mesmo tempo, a presença incontornável de um outro vai delimitar irredutivelmente essa entrada na modernidade, sua presença fundadora o transformará, de um lado, em figura mitificada e, de outro lado, figura controlada. Se é evidente que falo da descoberta e conquista da América e do quase extermínio dos seus habitantes nativos, falo também das possibilidades que se ganha - nesse longo intervalo - de experimentar novas formas e práticas de representação de si, do outro e do mundo. Isto é, para além de um mundo de formas e práticas de traços medievalizantes, estáveis e universais, de um pensamento analógico movido pela lógica da semelhança, a descoberta desse outro traz consigo a diferença como categoria demarcadora de práticas de representação até então indiscerníveis. É o que aponta Michel Foucault ao tratar o Quixote como arauto dessa ruptura: "Dom Quixote é a primeira das obras modernas, pois que aí se vê a razão cruel das identidades e das diferenças desdenhar infinitamente dos signos e das similitudes (...); pois que aí a semelhança entrará numa idade que é, para ela, a da desrazão e da imaginação" (1995, p. 63-4). Desrazão e imaginação, do louco e do poeta, respectivamente, que se tornarão representações por excelência para esse outro que a modernidade sempre insistiu em manter sob relativo controle e que vai adquirir vários outros nomes ao longo do tempo: selvagem, bárbaro, criança, mulher, negro, inconsciente, etc. A condição de "alteridade" será definida em relação à de "normalidade" que o ocidente moderno buscará assegurar como categoria "universal".

O discurso sobre o outro adquiriu na sociedade moderna o estatuto de saber científico, que se traduziu, fora do âmbito acadêmico, em posturas controladoras, bem como em políticas de dominação. Na verdade, esse outro não-ocidental e não-moderno, quando da sua "descoberta" pelo europeu, foi o deflagrador de importantíssimas mudanças na reconfiguração própria das sociedades ocidentais. É uma história necessária e que foi descrita habilmente por Afonso Arinos de Melo Franco no seu livro $O$ índio brasileiro e a Revolução Francesa, que inverte a tradicional lógica de influência das metrópoles para as colônias, ao rastrear o fluxo dos acontecimentos e das idéias que desaguarão na Ilustração Francesa do século XVIII como originários desse contato inaugural com o ameríndio. Esse é um processo de traços iluministas que resultará, no final do século XIX e início do século XX, na criação da ciência dedicada a estudar esse outro não-ocidental: a etnografia.

É, no entanto, contra esse saber e essa ciência que o outro hoje reaparece, a contrapelo dos discursos "civilizatórios", como uma espécie de outro de si próprio, com uma sanha digna do "mau selvagem" oswaldiano, reivindicando séculos de cafetinagem. Etnocentricamente considerado como povo sem escrita, sem história e sem Estado (cf. ROGNON, 1991, p. 17-27), esse "selvagem" contemporâneo se constitui, agora voluntariamente, como outro ao ocidente, do modo, frisese, como este se imagina. Uma de suas figuras - em devir histórico-político e já de alcance teórico-crítico - é o nômade. Ele representa com muita ênfase essa emergência de práticas insurgentes, pois historicamente o nômade se localiza como o exterior (notar bem: ele é o exterior, e não está no exterior) das grandes instituicões que as sociedades humanas tão eficientemente aparelharam: Família, I greja, Escola e Estado. Os nômades são considerados a escória da civilização humana. Povos coletores de frutas que a natureza oferece, não cultivam nada, não são agricultores, quando lidam com animais, caçam e pastoreiam de forma errante, em campo aberto, seguindo os animais, e não os conduzindo. Contrariamente ao sedentário, que constrói seu Território, cerca-o, domina-o, e aos que nele se encontram, produzindo um Estado, um Governo, uma Família, montando Instituições e Leis, o nômade tem uma prática social que não pode ser facilmente capturada e cooptada pelos aparelhos das sociedades sedentárias. Ele é definido por sua comunidade móvel, seus laços e práticas de representação não são do tipo estável. Essa comunidade não é permanente e fixa, mas rege e é regida por códigos de sociabilidade e subjetivação em constante e necessária transformação, até para a sobrevivência dos grupos. Não se trata de adaptação, mas de uma espécie de incessante deslizamento das leis e dos traços identificadores. Segundo o antropólogo e romancista Ruy Duarte de Carvalho, em seu estudo romanceado sobre os pastores nômades do sul de Angola, os Kuvale, Vou lá visitar pastores, o boi, por exemplo, é o traço mais poderoso em torno do qual a todas as esferas da vida dos kuvale giram: "é através do boi que um Macubal cresce, casa, faz filhos, prospera e come, e dança e brinca e dá sentido à vida" (CARVALHO, 2000, p. 185). Não se pode falar em harmonização ou em desaparecimento das fronteiras, mas há entre os nômades uma espécie de enfraquecimento acentuado que determinava no saber moderno a diferença entre eu e outro, homem e animal, homem e natureza nos povos sedentários. Além disso:

Muitas das imputações desabonatórias dirigidas aos Macubais são afinal as que, por todo o mundo e desde a Bíblia, estigmatizam as sociedades pastoris e todas aquelas que fundamentam na mobilidade as suas estratégias de vida. (...) muitos do lances mais decisivos e marcantes da história universal estão ligados a fluxos e a refluxos territoriais e culturais, invasões e expansões, recuos e dissoluções de grupos originariamente móveis e pastores. (...) não te faltarão materiais que tratam os aspectos ideológicos, econômicos e técnicos que traduzem os termos do conflito entre nómadas e os sedentários de hoje. Há ainda hoje na atualidade muitos milhões de seres humanos que extraem da sua mobilidade e dos seus recursos vivos e móveis as razões e as dinâmicas da sua vida econômica e cultural. (...) Os pastores são unanimemente acusados de independentes, pouco controláveis, pouco dóceis, pouco respeitadores das autoridades, turbulentos, bandidos, preguiçosos, avessos tanto aos trabalhos agrícolas como ao trabalho assalariado e público, rebeldes à escolarização, vítimas de arcaísmo cultural, de estagnação e de imobilismo, e, sobretudo, estão sempre prontos para roubar gados. (...) a mobilidade pode facilmente ser entendida como um factor de perturbação para os interesses das comunidades fixadas, agricultores na sua maioria legitimamente ciosos do controle absoluto sobre a terra que os mantém e os justifica. Acresce que os pastores de animais de grande porte de África que mais de perto nos podem interessar são, de uma maneira geral, embora em maior ou menor grau, também povos mais ou menos guerreiros ou que preservam traços culturais, logo comportamentais, de uma vocação e de uma capacidade guerreiras. (...) Na cabeça de um pastor, assim culturalmente modelado, esta circulação de animais corresponde a uma razão, a uma racionalidade, a uma 
Muito do que Ruy Duarte afirma sobre os Macubais, pode-se também achar com relativa facilidade em diversas sociedades contemporâneas, o que faz dos nômades, parafraseando o livro de Rognon, nossos contemporâneos, até mais, faz sermos nós próprios os nômades: uma mescla flutuante de territorialidade e deslocamento junto com os animais, o pesado estigma sobre essas populações, levando-os até a marginalidade e a criminalidade, o desconforto e até o perigo que sua lógica de vida impõe aos sedentarizados, uma cultura rebelde e guerreira, contrária aos saberes e controles da sociedade. Em outras palavras, tudo aquilo que hoje se faz tão característico da vida "pós-moderna" nas cidades "multiculturais", do primeiro ao terceiro mundo: as grandes migrações forçadas que fazem com que populações levem consigo seus valores culturais, entrando em conflito com as culturas dos locais que as recebem, as massas de jovens desempregados nas periferias das grandes cidades, muitos dos quais descendentes desses movimentos migratórios, a tecnologização que, se de um lado cria novas formas de controle, de outro lado provoca um incremento de uma contra-militarização criminosa. Assim, segredo e troca, territorialidade e desterritorialização, local e deslocamento são traços que ajudam a inscrever o nômade como um personagem forte da vida e das práticas públicas contemporâneas. Seja pelos grandes fluxos populacionais, tão característicos da vida do final do século XX, seja pela reivindicação generalizada de pautas particulares por grupos culturalmente marginalizados como negros, mulheres, indígenas, imigrantes e homossexuais, os processos de subjetivação nômades articulam uma severa crítica ao espaço público hipócrita da alta modernidade em nome da revalorização do domínio público como um ambiente em permanente e explícito estado de disputa - retórica e bélica. 0 nômade tem postura esquiva e agressiva, e produz sua violência, simbólica ou efetiva, a partir de elementos que afetam sua possibilidade de deslocar-se e de circular, isto é, de fazer valer seus desejos e vontades. Qualquer prática que o induza a fixar-se, que queira naturalizá-lo a partir de uma perspectiva que Ihe seja exterior, é imediatamente recusada. 0 exterior, para o nômade, é o campo de batalha, onde sua máquina de guerra trabalha sem piedade:

eu urrava nos poliedros da J ustiça meu momento abatido na extrema paliçada os professores falavam da vontade de dominar e da luta pela vida

as senhoras católicas são piedosas

os comunistas são piedosos

os comerciantes são piedosos

só eu não sou piedoso

se eu fosse piedoso meu sexo seria dócil e só se ergueria aos sábados à noite

eu seria um bom filho meus colegas me chamariam cu-de-ferro e me fariam perguntas por que navio bóia? Por que prego afunda?

iria a bailes onde eu não poderia levar meus amigos pederastas ou barbudos

eu me universalizaria no senso comum e eles diriam que tenho todas as virtudes

eu não sou piedoso

eu nunca poderei ser piedoso

(...) (PIVA, 2005, p. 41)

Todo nômade é um fundador e um destruidor de Estados; ele quer ser o próprio Estado. Não à maneira de um iluminado por Deus, como Luís XIV, cujo corpo pessoal era o próprio corpo político ("L'Etat c'est moi"), não à maneira dos governantes das modernas democracias que cobram condutas moralmente corretas na esfera pública sem compartilhar delas em ambientes privados, mas à maneira de um chefe indígena que só faz valer seu poder em tempos de guerra, pois sabe que o espaço público cotidiano pertence à subjetividade coletiva e imanente - sem transcendência e sem Deus. Em uma coletividade que não seja pensada e experimentada como projeto e projeção de uma entidade transcendente, a subjetividade nômade é vivida como subjetividade política no sentido forte, jamais de tipo meramente psicológica. 0 nômade sabe que a Lei vai inscrita no seu corpo, e é pela força que seu corpo pode produzir que ele intervém no domínio público e político. Para um nômade, a Lei, a Escrita e o Corpo formam "a tríplice aliança, [que] levada ao seu ponto extremo de estreitamento, elimina a própria necessidade da máquina [Estatal]: ou antes, é o prisioneiro em pessoa que se transforma em máquina de escrever a lei, e que a inscreve sobre seu próprio corpo" (CLASTRES, 1978, p. 125; grifo no original). Ou seja, o corpo do nômade é a sua própria máquina de escrever, a sua própria Lei, o seu próprio Estado, e com o seu corpo ele vai ao espaço público afirmar a si diante do outro e do mundo, não em nome de uma natureza universal, mas em nome de um sentimento e de um afeto que 0 tomam por inteiro e são parte de uma herança, de um mito comunitário qualquer que ele traz inscrito consigo à flor da pele. É o que afirma, de outra forma, Bruce Chatwin, em seu livro sobre sua viagem para encontrar mitos nômades dos aborígines australianos:

\begin{abstract}
... se acreditava que cada antepassado totêmico, ao viajar pelo país, houvesse espalhado um rastro de letras e notas musicais ao longo da linha de suas pegadas, e como esses traços do Sonho permaneciam sobre a terra como "meios" de comunicação entre as tribos mais distantes.

(...) Dando existência ao mundo pelo canto, ele disse, os Antepassados foram poetas no sentido original da poiesis, como "criação". Nenhum aborígine podia conceber que o mundo criado fosse de alguma forma imperfeito. Sua vida religiosa tinha uma única meta: manter a terra do jeito que era e deveria continuar 0 homem que saia em walkabout estava fazendo uma jornada ritual. Pisava nas pegadas do seu Antepassado. Cantava as estrofes do Antepassado sem mudar uma palavra ou nota - e assim recriava a Criação. (CHATWIN 1996, p. 23-5)
\end{abstract}

Essas práticas de representação conjugam fortemente elementos de produção de uma subjetividade avessa ao poder instituído com elementos provenientes de práticas consideradas menores até então recalcados pela racionalidade modern como ritualidades pagãs, festividades guerreiras e territorialidades fundadas em heranças e múltiplas tradições culturais. $E$ nesse momento que o espaço público é experimentado como corpo coletivo e o privado, como uma das partes desse mesmo corpo É como atualização de inúmeros e mesmo contraditórios processos de subjetivação, modernos e tradicionais, capitalistas e primitivos, civilizados e selvagens, que o nomadismo ganha formas e espaços dos mais repentinos na vida contemporânea. Trata-se de experimentar e afirmar papéis próprios aos povos nômades e que emergem (se desrecalcam?) e embaralham, no presente de culturas altamente tecnológicas, discursos e sujeitos confortavelmente instalados nos seus espaços "seguros", nos seus lugares (cf. MAFFESOLI, 2002). Leia-se ainda Roberto Piva, em 1961, na sua "Ode a Fernando Pessoa":

Quero que venhas compartilhar conosco as orgias da meia-noite, queremos ser para ti mais do que para o resto do mundo.

Nós, tenebrosos vagabundos de São Paulo

$(\ldots)$

Ah, vamos girar juntos pela cidade, não importa o que faças ou quem sejas, eu te abraço, vamos!

Alimentar o resto da vida com uma hora de loucura, mandar à merda todos os deveres, chutar os padres quando passarmos por eles nas ruas, amar os pederastas pelo simples prazer de traí-los depois,

Amar livremente mulheres, adolescentes, desobedecer integralmente uma ordem

Por cumprir, numa orgia insaciável e insaciada de todos os propósitos-Sombra.

(...)

Resumirei para Ti a minha história:

Venho aos trambolhões pelos séculos,

Encarno todos os fora-da-lei e todos os desajustados,

Não existe um gângster juvenil preso por roubo e nenhum louco sexual que eu não acompanhe para ser julgado e condenado;

Desconheço exame de consciência, nunca tive remorsos, sou como um lobo dissonante nas lonjuras de Deus. 
Os que me amam dançam nas sepulturas. (2005, p. 20-5)

0 ambiente público é tomado como um comum de práticas que abrangem, inclusive, a história. Não a história oficial dos livros escolares, mas a de onde se vem "aos trambolhões". Não lemos na poesia de Piva a sociedade como um espaço comum e anônimo, mas com os designativos acompanhando o pronome "nós", uma comunidade formada pelo sujeito do enunciado e por seus amigos: os "tenebrosos vagabundos de São Paulo". Subjetividades nômades que formam esse comum de práticas não como um "bem público", aberto e acessível a todos e a qualquer um, mas como uma série de traços exteriores e pontuais do grupo social que são os amigos e que no poema em questão vêm em Fernando Pessoa-Álvaro de Campos um aliado na batalha que travam, um aliado mais velho que aponta caminhos e com o qual querem compartilhar suas práticas "fora-da-lei".

Por práticas "fora-da-lei", tratemos de pensar em práticas de representação que transgridem qualquer idéia de natureza e de naturalidade, qualquer ímpeto em naturalizar uma cultura ou um discurso, a assunção de se viver à margem dos códigos e das convenções do corpo oficial, que acaba sempre por produzir um espírito de corpo, um corporativismo qualquer. ú familias - são sempre movimentos contra-natura. O "âmad") ṕc contra-natura, e por isso Piva afirma que c as pontos cardeais dos "nossos" elementos são: "contra a vagina pelo ânus, contra os espectros pelos fantasmas, contra as escadas pelas ferrovias, contra Eliot pelo Marquês de Sade" (PIVA, 2005, p. 135). Daí que o nômade é visto como um traidor. Ele peca contra todas as ordens instituídas, se rebela contra todos os poderes estabelecidos, investe contra todas as naturalizações, recusa todas as normalidades discursivas. Os nômades são as aspas da escrita contemporânea. Ele se desloca com velocidades surpreendentes, assim como surpresos ficam diante da suas táticas de subjetivações bruscas, que forçam todos a se localizarem, a assumirem seus fascismos mais ocultos e dissimulados. 0 nômade escancara à força o espaço público com aquilo que possui de mais público, exterioriza seu próprio exterior, explicita e assume a sua aparência como a única possível de ser suportada subjetivamente e a única ética para ser elaborada.

\section{Referências}

AUERBACH, Erich. "La court et la ville". In. LIMA, Luiz Costa. (org.) Teoria da literatura em suas fontes. 2 ed. Rio de Janeiro, Francisco Alves, 1983, pp. 150-90, vol II.

BAUDELAIRE, Charles. As flores do mal. Trad. Ivan J unqueira. Rio de Janeiro, Nova Fronteira, 1985 [Edição bilíngüe].

BAUDELAIRE, Charles. Obras estéticas. Petrópolis, Vozes, 1998

CAMÕES, Luís de. Obra completa. Rio de Janeiro, Nova Aguilar, 2003.

CARVALHO, Ruy Duarte de. Vou lá visitar pastores. Rio de Janeiro, Gryphus, 2000

CASTIGLIONE. Baldassare. O cortesão. São Paulo, Martins Fontes, 1997.

CHATWIN, Bruce. O rastro dos cantos. São Paulo, Companhia das Letras, 1996.

CLASTRES, Pierre. "Da tortura nas sociedades primitivas". A sociedade contra o Estado. Rio de J aneiro, Francisco Alves, 1978.

DAUVOIS, Nathalie. Le sujet lyrique à la Renaissance. Paris, PUF, 2000.

ELIAS, Norbert. O processo civilizador, vol.1. Rio de Janeiro, J orge Zahar, 1992.

FOUCAULT, Michel. As palavras e as coisas. São Paulo, Martins Fontes, 1995.

GÔNGORA, Luís de. Poemas. Trad. Péricles Eugênio da Silva Ramos. São Paulo, Art, 1988. [Edição bilíngüe]

GRACIÁN, Baltasar. A arte da prudência. São Paulo, Martins Fontes, 2001.

LÖWY, Michael, SAYRE, Robert. "Figuras do romantismo anticapitalista". Romantismo e política. São Paulo, Paz e Terra, 1993.

MAFFESOLI, Michel. Sobre o nomadismo: vagabundagens pós-modernas. Rio de Janeiro, Record, 2002.

PIVA, Roberto. Um estrangeiro na legião: obras reunidas I. São Paulo, Globo, 2005.

PSEUSO-DIONÍSIO, O AEROPAGITA. "Hierarquia celeste". Obras completas. São Paulo, Paulus, 2004

QUEIRÓZ, Eça de. "Alves \& Cia". Obra Completa. Rio de Janeiro, Nova Aguilar, 1997, vol 2.

REBELO, Luís de Sousa. "Armas e letras: um topos do humanismo cívico". A tradição clássica na literatura portuguesa. Lisboa, Horizonte Universitário, 1982.

RIBEIRO, Renato J anine. "A fortuna aristocrática". A última razão dos reis. São Paulo, Companhia das Letras, 1993.

ROGNON, Frédéric. Os primitivos, nossos contemporâneos. São Paulo, Papirus, 1991

ROSSET, Clément. A anti-natureza: elementos para uma filosofia trágica. Rio de Janeiro, Espaço e Tempo, 1989.

SENNETT, Richard, O declínio do homem público. As tiranias da intimidade. São Paulo, Companhia das Letras, 1998.

TODOROV, Tzvetan. O espírito das Luzes. São Paulo, Barcarola, 2008.

VEGA, Gracilaso de la. Poesía castellana completa. Madrid, Ediciones Cátedra, 1999.

VERDE, Cesário. Poesia completa e cartas selecionadas. São Paulo, Cultrix, EDUSP, 1982.

Recebido em 16/09/2008. Aprovado em 28/10/2008.

\section{Resumos}

Title: The Courtier, the Dandy, and the Nomad: notes on subjectivation processes and Cultural History

Author: Sandro Ornellas

Abstract: Thoughts over different subjectiving processes that have produced three conceptual characters along the cultura history. The 16th century coutier, the 19th century dandy and the contemporaneous nomad all result from historical changes in the notion of public and private, artifice and nature, exteriority and interiority, social rules and expontanety, appearance and essence that serves, mainly, to distress the lack of continuance in cultural behaviours that, at a first sight, would seem to be simple processes of history repetition. For beyond the historical characters, their approximation enables a reevaluation of how the contemporaneous culture places itself along some subjectivity historical changes, that is, then, faced less as a psychological data and more as result of political-historical-cultural processes.

Keywords: subjectivizing; cultural history; conceptual characters; courtier, dandy, nomad.

Titre: Le courtisan, le dandy et le nomade: notes sur les procès de subjectivation et histoire culturelle

Auteur: Sandro Ornellas

Résumé: II s'agit d'une réflexion sur différents procès de subjectivation qui ont produit trois personnages conceptuels tout au long de l'histoire mondiale. Le courtisan du seizième siècle, le dandy du dix-neuvième siècle et le nomade contemporai dérivent de changements historiques dans les notions de publique et privé, artifice et nature, extériorité et intériorité, convention et spontanéité, apparence et essence qui servent surtout pour détacher les discontinuités dans les conduites culturels lesquels, à première vue, pourraient paraître de simples procès de répétition de l'histoire. Au-delà de figures culturels lesquels, à première vue, pourraient paraître de simples procès de répétition de l'histoire. Au-delà de figures
historiques, l'approche de ces trois personnages rend possible une réévaluation concernant comment la culture contemporaine se place tout au long de quelques transformations historiques de la subjectivité, qui est alors envisagée moins comme une donnée psychologhique et plus comme un produit de procès politico-historique-culturels.

Mots-clés: procès de subjectivation, histoire culturelle, personnages conceptuels, courtisan, dandy, nomade.

Título: El cortesano, el dandy y el nómada: notas sobre los procesos de subjetivación e historia cultural

Autor: Sandro Ornellas

Resumen: Reflexión sobre diferentes procesos de subjetivación que produjeron tres personajes conceptuales a lo largo de la historia cultural. El cortesano quinientista, el dandy ochocentista y el nómada contemporáneo derivan de cambios históricos de las nociones de público y privado, artificio y naturaleza, exterioridad e interioridad, convención y espontaneidad, apariencia y esencia que sirven, sobretodo, para destacar los descontinuos en los comportamientos culturales que, en un primer momento, podrian parecer simples procesos de repetición de la historia. Además de figuras históricas, el acercamiento a los tres personajes permite una reevaluación de cómo la cultura contemporánea se posiciona a lo largo de algunas transformaciones 
históricas de la subjetividad que se ve menos como algo psicológico y más como un producto de los procesos político-históricoculturales.

Palabras-clave: proceso de subjetivación, historia cultural, personajes conceptuales, cortesano, dandy, nómada.

\section{Notas}

[1] Na tradução de Ivan Junqueira: "A natureza é um templo onde vivos pilares / Deixam filtrar não raro insólitos enredos; / 0 homem o cruza em meio a um bosque de segredos / Que ali o espreitam com seus olhos familiares. // Como ecos longos que à distância se matizam / Numa vertiginosa e lúgubre unidade, / Tão vasta quanto a noite e quanto a claridade, / Os sons, as cores e os perfumes se harmonizam. // Há aromas frescos como a carne dos infantes, / Doces como o oboé, verdes como a campina, / E outros, já dissolutos, ricos e triunfantes, I/ Com a fluidez daquilo que jamais termina, / Como 0 almíscar, o incenso e as resinas do Oriente, / Que a glória exalta dos sentidos e da mente" (BAUDELAIRE, 1985, p. 115).

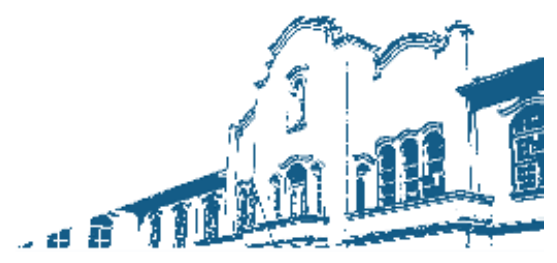

Copyright PPGCL/ Unisul 2006 @ (48) 3621-3369 - Desenvolvimento: Prof. Dr. Fábio J osé Rauen 